\title{
Isolasi dan Identifikasi Bakteri Salmonellasp dan Serratia sp Pada Eksoskeleton Lalat Hijau (Chrysomya megacephala)
}

\section{Isolation and Identification of Salmonella sp and Serratia sp Bacteria in the Exoskeleton of the Green Fly (Chrysomya megacephala)}

\author{
Rizal Maarif Rukmana ${ }^{1^{*}}$, Rika Siwi Utami ${ }^{2}$ \\ ${ }^{1}$ Program Studi D-IV Analis Kesehatan, ${ }^{2}$ Program Studi D-III Analis Kesehatan \\ Fakultas Ilmu Kesehatan, Universitas Setia Budi \\ J1. Letjen Sutoyo Mojosongo, Surakarta, Jawa Tengah 57127, Indonesia \\ *Corresponding author: rizal.nerazuri@gmail.com
}

Received: February 12, 2019; Revise: April 15, 2019; Accepted: May 18, 2019

DOI: https://doi.org/10.31001/biomedika.v12i1.417

\begin{abstract}
ABSTRAK
Lalat Chrysomya megacephala merupakan salah satu spesies yang sering ditemukan di sekitar manusia khususnya di Pasar Tradisional. Lalat Chrysomya megacephala merupakan salah satu vektor berbagai macam penyakit yang ditimbulkan oleh: bakteri, parasit dan helmin. Tujuan penelitian ini adalah untuk mengetahui apakah pada eksoskeleton Lalat Chrysomya megacephala membawa bakteri Salmonella sp dan Serratia sp. Metode yang dipakai dalam menangkap Lalat Chrysomya megacephala adalah dengan menggunakan kertas umpan berperekat.Lalat Chrysomya megacephala yang ditangkap sebanyak 30 ekor. Lalat kemudian dilakukan identifikasi. Tahap selanjutnya dilakukan isolasi bakteri genus Salmonella sp dan Serratia sp pada Lalat Chrysomya megacephala dengan menggunakan Salmonella Shigella Agar (SSA) dan Endo Agar (EA). Identifikasi dilakukan dengan melakukan pengamatan koloni, uji biokimia dan pengecatan gram. Hasil yang didapatkan yaitu ditemukan bakteri Serratia sp pada eksoskeleton Lalat Chrysomya megacephala sebanyak 90 \%. Bakteri Salmonella sp teridentifikasi 63,33\% ada pada eksoskeleton Lalat Chrysomya megacephala. Bakteri Salmonella sp dan Serratia spyang teridentifikasi pada Lalat Chrysomya megacephala adalah 30\%. Lalat Chrysomya megacephala yang didapatkan dari Pasar Mojosongo Surakarta terdeteksi sebagai vektor dari bakteri Salmonella sp dan Serratia sp.
\end{abstract}

Kata kunci: Chrysomya megacephala; Salmonella sp; Serratia sp

\section{ABSTRACT}

Chrysomyamegacephala is one species that often found around humans, especially in Traditional Markets. Chrysomyamegacephala is one vector of various diseases caused by: bacteria, parasites and helmin. The purpose of this study was to determine whether the exoskeleton of the Chrysomyamegacephala carries the bacteria Salmonellasp and Serratia sp. The method used in catching the Chrysomyamegacephala is by using adhesive bait paper. Number of Chryosomya megacephala samples is 30. Chryosomya megacephalaare then identified. The next step is the isolation of the bacterium Salmonella sp and Serratiasp in the Chrysomyamegacephala using Salmonella Shigella Agar (SSA) and Endo Agar (EA). Identification is done by observing colonies, biochemical tests and gram staining. The results obtained were found in Serratiasp on the exoskeleton of the Chrysomyamegacephalaas much as $90 \%$. Salmonellasp bacteria identified $63.33 \%$ on the exoskeleton of the Chrysomyamegacephala. Salmonellasp and Serratiasp bacteria identified in the Chrysomyamegacephala are 30\%.Chrysomyamegacephala flies obtained from the Surakarta Mojosongo Market are accepted as vectors of Salmonellasp and Serratia sp.

Keyword: Chrysomya megacephal; Salmonella sp; Serratia sp 


\section{PENDAHULUAN}

Arthrophoda memiliki peranan penting di berbagai sektor di Dunia kesehatan. Peran Arthrophoda tersebut diantaranya ada pada sektor epidemiologi, kesehatan masyarakat dan forensik. Peran tersebut sangat berkaitan dengan hubungan antara Arthrophoda yang sering membawa mikroorganisme pada tubuhnya seperti: bakteri, virus, parasit dan helmin. Mikroorganisme tersebut bertanggung jawab atas penyebaran penyakit seperti disentri, kolera, botulisme, demam tifoid, brucellosis, polio, cacar, TBC, kolera, konjungtivitis, kusta dan penyakit lainnya (Carneiro et al., 2014).Lalat hijau atau dalam bahasa ilmiahnya disebut Chrysomya megacephalamerupakan anggota dari FilumArthropoda dan termasuk ke dalam ordo Diptera.

Chrysomya

megacephala

mempunyai peran dalam kesehatan masyarakat, yaitu sebagai vektor penularan penyakit. Chrysomya megacephala berperan sebagai vektor mekanis dan biologis dalam penularan penyakit. Penularan secara mekanis dapat terjadi pada bagian tubuh dari Chrysomya megacephala yang membawa bibit-bibit penyakit melalui anggota tubuh seperti kepala, thorax, abdomen, rambut-rambut pada kaki, sayap dan mulutnya. Penularan secara biologis dapat dilakukan dengan cara Chrysomya megacephala hinggap pada makanan dan mengeluarkan air liurnya yang mengandung bakteri patogen. Chrysomya megacephala mampu terbang antara 1-2 mill per hari dan dapat membawa bakteri dari berbagai tempat ke tempat lain yang disinggahi (Safitri et al., 2017).
Beberapa bakteri yang sering ditemukan pada Lalat diantaranya: Salmonella, Shigella, Escheriscia coli, Staphylococcus (Safitri et al., 2017) Aquaspirillum polymorphum, Burkholderia ambifaria, Burkholderia anthina, Burkholderia cepacia, Burkholderia cenocepacia, Burkholderia pyrrocinia, Burkholderia stabilis, Paenibacillus macerans, Virgibacillus pantothenticus, Bacillus subtilis (Carneiro et al., 2014). Carneiro et al., (2014) melakukan penelitian pada Lalat di Brazilia dan Safitri et al., (2017) melakukan penelitian pada Lalat di Surabaya, Indonesia. Bakteri Serratia sp sering ditemukan pada air dan tanah, pada permukaan daun, serta pada eksoskeleton serangga, pada tubuh hewan, dan di dalam tubuh manusia (Priyatno et al., 2011).

Beberapa bakteri yang sering terdapat pada eksoskeleton Lalat adalah bakteri Salmonella sp. Bakteri Salmonella sp termasuk kedalam bakteri yang bersifat patogen. Bakteri Salmonella sp termasuk dalam famili Enterobacteriaceae yang merupakan bakteri enterik (Astawa dan Tarini, 2017). Bakteri enterik adalah bakteri yang bisa bertahan didalam saluran pencernaan rongga mulut, esofagus, lambung, usus, rectum, dan anus. Bakteri enterik dikategorikan sebagai anaerob fakultatif (bakteri yang dapat hidup dengan baik bila ada oksigen maupun tidak ada oksigen) dan termasuk flora normal gastrointestinal namun dapat menyebabkan infeksi primer pada sistem gastrointestinal (Hestiningsih et al, 2004). Bakteri Serratia sp merupakan genus bakteri yang mempunyai sebaran luas di lingkungan. Bakteri Serratia sp secara umum terdapat di tanah, air, berassosiasi dengan tanaman, 
hewan dan insekta. Beberapa studi menyatakan bahwa bakteri Serratia sp dapat menyebabkan penyakit pneumonia. Bakteri Serratia sp juga sering ditemukan pada aliran darah, saluran kencing dari pasien yang di rawat di Rumah Sakit. Infeksi yang lainnya yang sering terjadi akibat Serratia sp yaitu infeksi septikemia (Mahlen, 2011).

Chrysomya megacephalabanyak ditemukan pada pasar-pasar tradisional. Adanya populasi lalat di pasar sangat berkaitan dengan kejadian dan penyebaran penyakit oleh agen infeksi yang berasal dari tempat tersebut. Salah satu pasar yang menjadi pusat perbelanjaan masyarakat di daerah Surakarta adalah Pasar Mojosongo. Pasar Mojosongo merupakan tempat aktivitas jual beli untuk mendapatkan berbagai jenis bahan makanan, seperti ikan, daging, sayur dan buah.Aktivitas jual-beli di dalam pasar tersebut akan menghasilkan sampah dan menjadikan lingkungan pasar yang kurang bersih. Selain itu, pada musim hujan biasanya di pasar tersebut banyak terdapat genangan air. Sampah yang membusuk dan banyak genangan air mendukung untuk hidup dan berkembangbiak lalat.

Hasil penelitian sebelumnya yang telah dilakukan oleh Putri (2018) menyatakan bahwa Lalat rumah (Musca domestica Linn) yang diperoleh dari Pasar Jakabaring Palembang teridentifikasi sebagai vektor dari bakteri Salmonella $\mathrm{sp}$ dan Proteus sp.Menurut Ibrahim et al (2018), bagian eksoskeleton Lalat Musca domestica Linn teridentifikasi bakteri Escherichia coli, Salmonella sp,

Pseudomonas sp, Shigella sp, Klebsiella sp, Staphylococcus sp, Streptococcus sp, Bacillus spdanProteus sp.Hasil penelitian Sukmawati et al, (2018) menunjukkan bahwa Lalat Hijau (Chryosoma megacephala) yang diperoleh dari Rumah Potong Unggas (RPU) teridentifikasi bakteri Salmonella sp,Shigella, Escherichia coli, Vibrio vulnificus, Vibrio Algimolyticus, Vibrio mimicus, Vibrio cholerae dan Vibrio carchariae. Hasil tersebut menujukkan bahwa Lalat Hijau (Chryosoma megacephala) merupakan vektor dari bakteri pathogen. Lalat selain sebagai vektor dari bakteri ternyata pada bagian tubuhnya terdapat jenis bakteri yang berbeda-beda. Pada penelitian ini akan dilakukan identifikasi bakteri Salmonella sp dan Serratia sp pada Lalat Hijau (Chryosoma megacephala) yang diperoleh dari Pasar Mojosongo Surakarta. Selain itu, penelitian ini akan memberikan informasi bakteri patogen yang sering ditularkan oleh Lalat Hijau di Pasar Mojosongo, Surakarta.

\section{METODE PENELITIAN}

\section{Alat dan Bahan}

Penelitian dilaksanakan di laboratorium Parasitologi dan Mikrobiologi Universitas Setia Budi Surakarta. Sampel lalat Chrysomya megacephaladiperoleh dari Pasar Mojosongo dengan menggunakan umpan perekat. Lalat yang ditangkap sebanyak 30 ekor. Alat yang digunakan dalam penelitian ini adalah pinset, tabung reaksi, rak tabung reaksi, sentrifuge, objek glass, minyak emersi, mikroskop, jarum ose, spiritus, kapas, cawan petri dan inkubator.

Bahan dan media yang digunakan pada penelitian ini diantaranya: Endo agar (EA), Salmonella Shigella Agar (SSA), BHI, Kliger's Iron Agar (KIA), Lysin Iron Agar 
(LIA), Sulfida Indol Motilitas (SIM), Citrat, Aquades steril, Erlich A dan Erlich B.

\section{Prosedur Penelitian}

\section{Pengambilan Sampel Lalat Chrysomya megacephala}

Disediakan umpan kertas berperekat dan dilektakkan di sekitar Pasar Mojosongo. Umpan kertas berperekat didiamkan selama dua jam untuk menarik datangnya Lalat ke umpan. Umpan kertas berperekat diambil setelah 2 jam beserta sampel Lalat yang terperangkap pada umpan tersebut. Lalat dikoleksi dan dibawa ke Laboratorium. Lalat yang dikoleksi kemudian dilakukan identifikasi dengan menggunakan buku acuan dari: Soulsby (1986) dan Sasmita et al., (2013).

\section{Isolasi Bakteri pada Lalat Chrysomya megacephala}

Isolasi bakteri pada eksoskeleton lalat Chrysomya megacephala dengan: Lalat yang diperoleh dari pasar dimasukkan kedalam tabung reaksi yang sebelumnya telah berisi BHI $5 \mathrm{ml}$. Tabung tersebut di sentrifuge selama 5 menit dengan kecepatan $3000 \mathrm{rpm}$. Tabung yang telah di sentrifuge kemudian dipisahkan dari supernatannya, maka akan didapatkan sisa sedimen untuk bahan uji pemeriksaan. Sampel sedimen dihomogenkan, kemudian dilakukan inokulasi bakteri dengan jarum ose dan digoreskan ke cawan petri pada media Endo Agar (EA) dan Salmonella Shigella Agar (SSA) secara aseptis. Cawan petri dibungkus kemudian diinkubasi pada suhu $37^{\circ} \mathrm{C}$ Selama 24 jam sampai 48 jam (Saidah, 2011).

3. Identifikasi Bakteri Salmonella sp pada Lalat Chrysomya megacephalaKultur Pada Media Salmonella Shigella Agar (SSA)

Sampel dari BHI diinokulasikan pada media Salmonella Shigella Agar (SSA). Cawan petri kemudian diinkubasi ke dalam inkubator selama 24 jam sampai 48 jam. Pengamatan dilakukan pada koloni yang tumbuh dengan ciri koloni: kecil, bulat, tepi halus, pada bagian tengah berwarna hitam/gelap.

\section{Uji Biokimia}

Dari media Salmonella Shigella Agar diambil salah satu koloni Salmonella sp yang telah diamati sesuai dengan ciri-cirinya kemudian dilakukan pemeriksaan makroskopis dengan uji biokimia dengan jarum ose mengambil koloni dan ditanam pada media Kliger's Iron Agar (KIA), Lysin Iron Agar (LIA), Sulfida Indol Motilitas (SIM) dan Citrat.

\section{Pengecatan Gram}

Dari media Salmonella Shigella Agar diambil salah satu koloni Salmonella $s p$ yang telah diamati sesuai dengan ciri-cirinya kemudian dilakukan pemeriksaan mikroskopis dengan pengecatan gram. Bakteri Serratia sp diambil dari koloninya kemudian digoreskan pada obyek glass bebas lemak yang sebelumnya sudah ditambah 1-2 tetes aquades steril. Ratakan goresan tersebut hingga $2 \times 3 \mathrm{~cm}$. Kemudian ditunggu sampai kering, dan dilakukan fiksasi agar sel-sel bakteri mati. Letakkan preparat yang sudah 
difiksasi pada rak pengecatan. Diteteskan 2-3 tetes larutan gram A pada preparat dan didiamkan selama 1 menit. Setelah itu dilakukan pencucian dengan air mengalir sampai cat tercuci semuanya. Selanjutnya diteteskan 2-3 tetes larutan gram B dan didiamkan selama 1 menit, lalu dilakukan pencucian dengan air mengalir. Cat dilunturkan dengan larutan gram $\mathrm{C}$ sampai lapisan tampak pucat (30 detik) dan dilakukan pencucian dengan air mengalir. Diteteskan cet penutup gram D dan didiamkan selama 2 menit. Selanjutnya dilakukan pencucian dengan air mengalir dan dikering anginkan. Berikutnya dilakukan pengamatan dibawah mikroskop mulai dari perbesaran 100x (Saidah, 2011).

\section{Identifikasi Bakteri Serratia sp pada}

\section{Lalat Chrysomya megacephala}

Kultur Pada Media Endo Agar

Sampel dari BHI diinokulasikan pada media Endo Agar (EA). Cawan petri kemudian diinkubasi ke dalam inkubator selama 24 jam sampai 48 jam. Pengamatan dilakukan pada koloni yang tumbuh dengan ciri koloni: bulat, kecil, cembung dan membentuk pigmen merah

\section{Uji Biokimia}

Dari media Endo Agar diambil salah satu koloni Serratia sp yang telah diamati sesuai dengan ciri-cirinya kemudian dilakukan pemeriksaan makroskopis dengan uji biokimia dengan jarum ose mengambil koloni dan ditanam pada media Kliger's Iron Agar (KIA), Lysin Iron Agar (LIA), Sulfida Indol Motilitas (SIM) dan Citrat.

\section{Pengecatan Gram}

Dari media Endo Agar diambil salah satu koloni Serratia sp yang telah diamati sesuai dengan ciri-cirinya kemudian dilakukan pemeriksaan mikroskopis dengan pengecatan gram. Bakteri Serratia sp diambil dari koloninya kemudian digoreskan pada obyek glass bebas lemak yang sebelumnya sudah ditambah 1-2 tetes aquades steril. Ratakan goresan tersebut hingga $2 \times 3 \mathrm{~cm}$. Kemudian ditunggu sampai kering, dan dilakukan fiksasi agar sel-sel bakteri mati. Letakkan preparat yang sudah difiksasi pada rak pengecatan. Diteteskan 2-3 tetes larutan gram A pada preparat dan didiamkan selama 1 menit. Setelah itu dilakukan pencucian dengan air mengalir sampai cat tercuci semuanya. Selanjutnya diteteskan 2-3 tetes larutan gram B dan didiamkan selama 1 menit, lalu dilakukan pencucian dengan air mengalir. Cat dilunturkan dengan larutan gram $\mathrm{C}$ sampai lapisan tampak pucat (30 detik) dan dilakukan pencucian dengan air mengalir. Diteteskan cet penutup gram D dan didiamkan selama 2 menit. Selanjutnya dilakukan pencucian dengan air mengalir dan dikering anginkan. Berikutnya dilakukan pengamatan dibawah mikroskop mulai dari perbesaran 100x (Saidah, 2011).

\section{HASIL DAN PEMBAHASAN}

1. Bakteri yang Teridentifikasi Pada Eksoskeleton Chrysomya megacephala

$\begin{array}{cccr}\text { Pada } & \text { Tabel } & 1 & \text { tersebut } \\ \text { menunjukkan } & \text { bahwa } & \text { dari } & \text { sampel }\end{array}$


eksoskeleton

Chrysomya megacephalayang diperoleh dari Pasar Mojosongodidapatkan 9 sampel teridentifikasi bakteri Salmonella sp dan Serratia sp. Hasil tersebut menunjukkan Lalat Chrysomya megacephala selalu membawa mikrobia patogen antara Salmonella $\mathrm{sp}$ dan Serratia sp atau dua-duanya.

Tabel 1. Bakteri Salmonella sp dan Serratia sp pada eksoskeleton Chrysomya megacephala.

\begin{tabular}{lccc}
\hline No & Bakteri yang & Jumlah & $\%$ \\
& Teridentifikasi & C.megacephala & C.megachephala \\
\hline 1 & Salmonella sp & 19 & 63,33 \\
2 & Serratia $\mathrm{sp}$ & 27 & 90,00 \\
3 & Salmonella $\mathrm{sp}$ & 9 & 30,00 \\
& dan Serratia & & \\
& sp & & 100 \\
& Total Sampel & 30 & \\
\hline
\end{tabular}

2. Hasil Isolasi dan Identifikasi Bakteri Salmonella sp dari Eksoskeleton Chrysomya megacephala Pada Media Salmonella Shigella Agar

Hasil isolasi bakteri Salmonella sp dari eksoskeleton C.megacephala pada media Salmonella Shigella Agar (SSA) dapat dilihat pada gambar 1 .

Hasil gambar 1 menunjukkan bahwa ciri-ciri koloni dari Salmonella sp yang tumbuh pada media Salmonella Shigella Agar yaitu: bentuk bulat kecil, tepi rata, koloni tengah berwarna hitam/gelap.

\section{Hasil Identifikasi Bakteri Salmonella} sp pada Media Uji Biokimia.

Hasil identifikasi bakteri Salmonella sp pada media uji biokimia dapat dilihat pada gambar 2 .

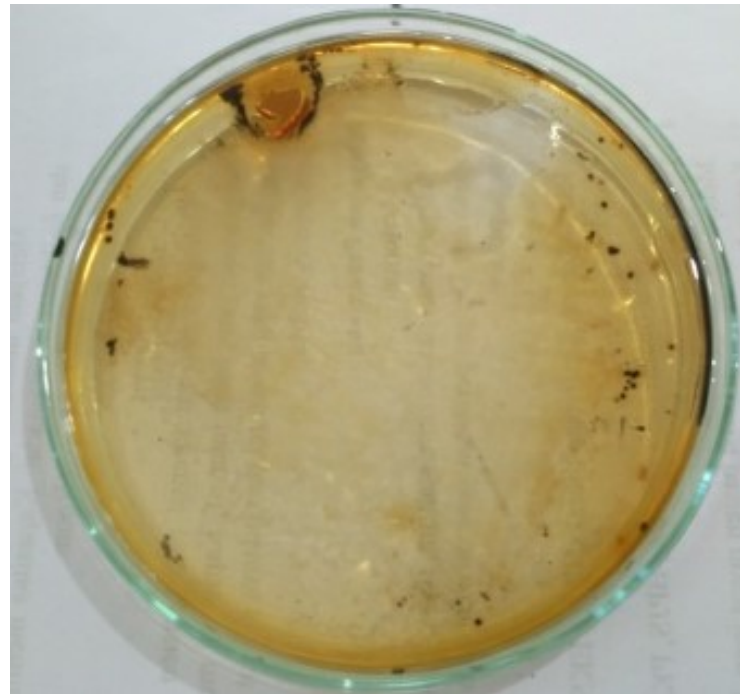

Gambar 1. Koloni dari bakteri Salmonella sp yang tumbuh pada media Salmonella Shigella Agar.

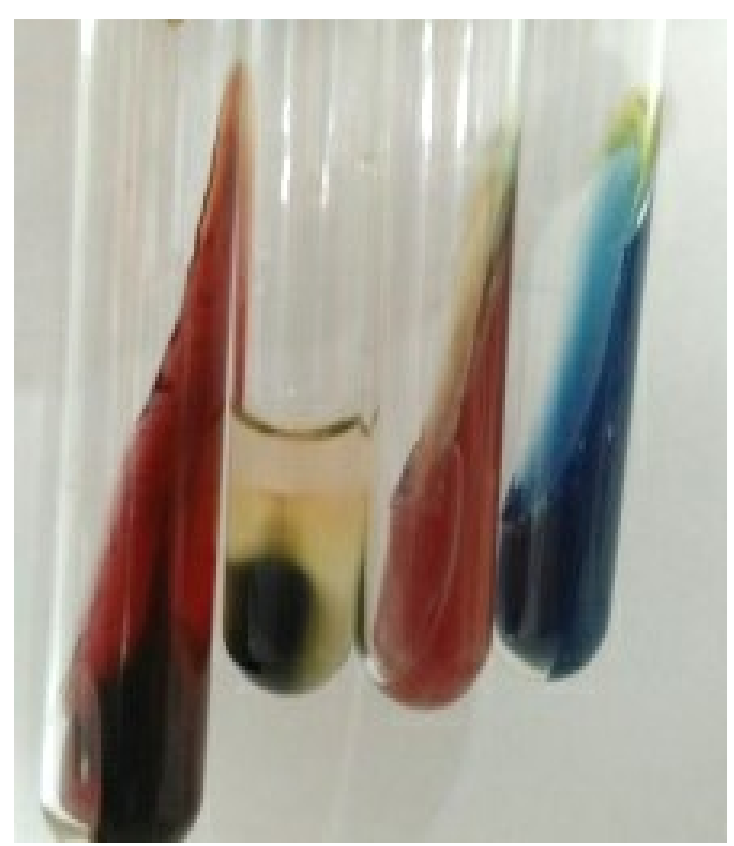

Gambar 2. Hasil uji biokimia dari bakteri Salmonella sp

Berdasarkan hasil uji biokimia tersebut, maka dilakukan pembacaan uji biokimia Salmonella sp dan hasil pembacaannya dapat dilihat pada Tabel 2 . 
Tabel 2. Hasil Pembacaan Uji Biokimia Bakteri Salmonella sp Sampel dari Lalat C.megacephalayang diperoleh dari Pasar Mojosongo

\begin{tabular}{clc}
\hline No. & \multicolumn{1}{c}{ Media } & Sampel dari Pasar \\
\hline 1. & KIA & $\mathrm{K} / \mathrm{AG}+\mathrm{S}+$ \\
2. & SIM & +-+ \\
3. & LIA & $\mathrm{K} / \mathrm{KS}+$ \\
4. & CITRAT & + \\
\hline
\end{tabular}

\section{Hasil Identifikasi Bakteri Salmonella sp pada Pengecatan Gram}

Hasil identifikasi bakteri Salmonella sp dengan menggunakan pengecatan gram dapat dilihat pada gambar 3. Salmonella $\mathrm{sp}$ dengan pengecatan gram Pada gambar 3 menunjukkan bahwa hasil pengecatan gram dari Salmonella sp mempunyai ciriciri: gram negatif (warna merah), bentuk batang (basil). Hal tersebut merupakan ciri-ciri dari bakteri Salmonella sp.

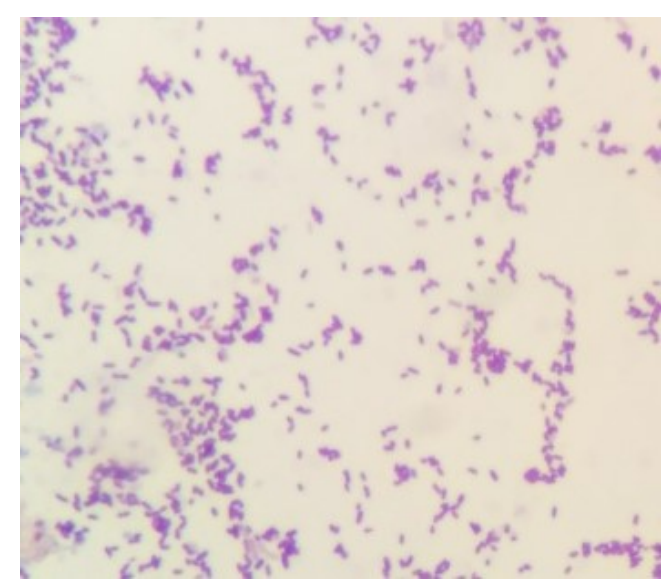

Gambar 3. Hasil identifikasi bakteri

4. Hasil Isolasi dan Identifikasi Bakteri Serratia sp dari Eksoskeleton Chrysomya megacephala Pada Media Endo Agar

Hasil isolasi bakteri Serratia sp dari eksoskeleton C.megacephala pada media Endo Agar (SSA) dapat dilihat pada gambar 4 .

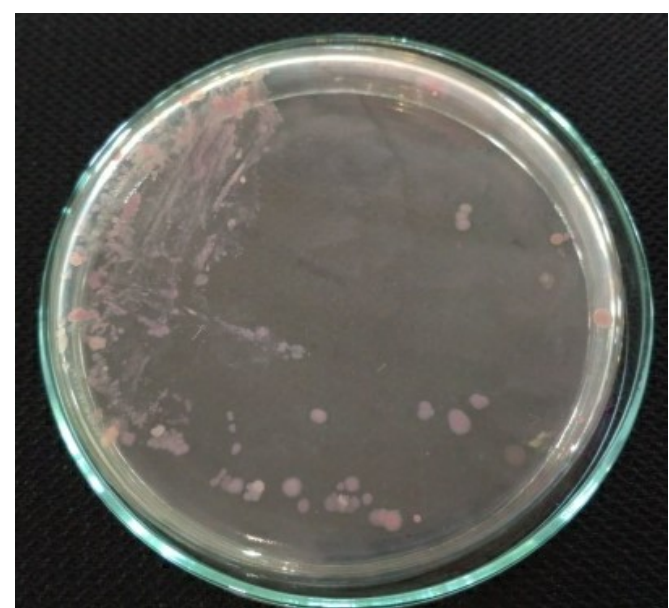

Gambar 4. Koloni dari bakteri Serratia sp yang tumbuh pada media Endo Agar

Pada gambar 4 tersebut menunjukkan ciri-ciri koloni bakteri Serratia sp yang diisolasi dari eksoskeleton C.megacephala Pasar Mojosongo yaitu: koloni bulat, kecil, membentuk pigmen merah. Hal tersebut sesuai dengan ciri-ciri koloni bakteri Serratia sp pada umumnya.

\section{Hasil Identifikasi Bakteri Serratia sp pada Media Uji Biokimia}

Hasil identifikasi bakteri Serratia sp pada media uji biokimia dapat dilihat pada gambar 5 .

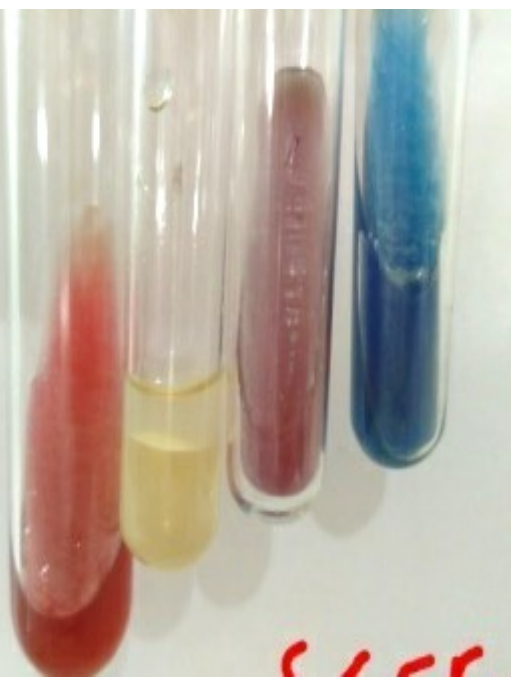

Gambar 5. Hasil uji biokimia dari bakteri Serratia sp 
Berdasarkan hasil uji biokimia tersebut, maka dilakukan pembacaan uji biokimia bakteriSerratiasp dan hasil pembacaannya dapat dilihat pada Tabel 3 .

Tabel 3. Hasil Pembacaan Uji Biokimia Bakteri Serratia sp Sampel dari Lalat C.megacephalayang diperoleh dari Pasar Mojosongo

\begin{tabular}{clc}
\hline No. & Media & Sampel dari Pasar \\
\hline 1. & KIA & K/AG+S- \\
2. & SIM & --+ \\
3. & LIA & K/KS- \\
4. & CITRAT & + \\
\hline
\end{tabular}

\section{Hasil Identifikasi Bakteri Serratia sp pada Pengecatan Gram}

Hasil identifikasi bakteri Serratia sp dengan menggunakan pengecatan gram dapat dilihat pada gambar 6. Pada gambar 6 menunjukkan bahwa hasil pengecatan gram dari Serratia sp mempunyai ciri-ciri: sifat adalah gram negatif, berwarna merah, bentuk batang (basil) dan susunan menyebar. Hal tersebut merupakan ciri-ciri dari bakteri Serratia sp saat dilakukan pengecatan gram.

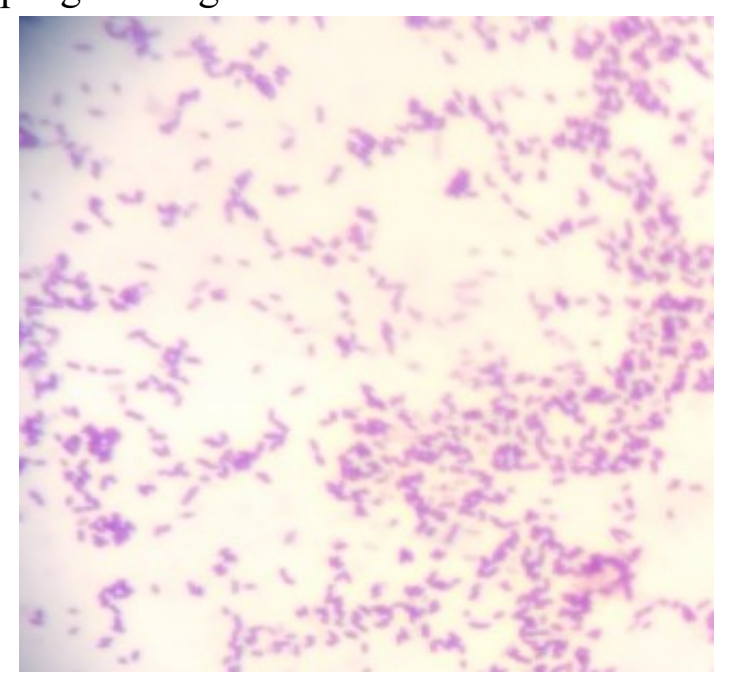

Gambar 6. Hasil identifikasi bakteri

Serratia sp dengan pengecatan gram
Serratia sp merupakan bakeri yang paling banyak ditemukan dalam penelitian ini. Sifat bakteri Serratia sp adalah patogen oportunistik atau bakteri akan menyerang tubuh inangnya ketika tubuh inang dalam kondisi kurang baik (kesehatannya menurun) (Astawa dan Tarini, 2017). Serratia sp adalah bakteri gram negatif famili Enterobateriaceae yang memiliki flagella peritrik, sehingga bersifat motil. Salah satu anggota dari genus Serratia yang dapat menyebabkan infeksi pada manusia adalah Serratia liquifaciens. Bakteri ini dapat menyebabkan pneumonia, bakteremia dan endokarditis terutama pada pasien yang dirawat di rumah sakit (Rengkuan et al., 2016).

Salah satu ciri dari anggota genus Serratia adalah terdapatnya pigemn merah pada koloni bakteri. Pigmen merah tersebut diproduksi oleh prodigiosin dari genus Serratia. Pigmen merah prodigiosin tersebut tergolong dalam famili pigmen merah tripyrole yang mengandung 4methoxy, ring 2-2 bipyrolle. Prodigiosin merupakan senyawa metabolit sekunder dari genus Serratia yang mempunyai beberapa aktivitas diantaranya adalah sebagai antibakteri, antifungi, dan antiprotozoa. Prodigiosin bersifat sitotoksik dan dapat digunakan sebagai pewarna alami untuk sutera dan wol (Priyatno et al., 2011).

Genus Serratia memiliki distribusi yang sangat luas di alam. Beberapa spesies dari Serratia dapat hidup pada insekta (serangga), mammalia, air, tanah dan tumbuhan. Beberapa contoh spesies dari genus Serratia yang dapat hidup pada air, tanah, serangga dan mammalia yaitu: S.liquifaciens, S.marcescens, S.plymutica, 
S. proteamaculans, S.quiniforans. Anggota genus Serratia yang dapat menyebabkan infeksi manusia salah satunya adalah S.marcescens. Bakteri S.marcescens merupakan bakteri yang sangat penting dalam infeksi terhadap manusia. Bakteri S. entomophila, S. glossinae, S. proteamaculans, S. nematodiphila, dan S. ureilyticasangat jarang ditemukan dapat menginfeksi manusia (Mahlen, 2011).

Bakteri Salmonella sp juga telah ditemukan pada eksoskeleton dari Lalat C.megacephala yang ditangkap di Pasar Mojosongo. Hal tersebut menunjukkan bahwa Lalat C.megacephalamerupakan vektor pembawa mikrobia patogen. Bakteri Salmonella bakteri yang dapat menyebabkan penyakit Salmonellosis. Bakteri Salmonella sp biasanya banyak ditemukan di air susu, daging, ayam, anak ayam. Menurut Safitri et al., (2017) anak ayam sangat rentan terhadap infeksi Salmonella karena mudah tertular dari induknya.

Penyakit Salmonellosis merupakan penyakit zoonosis yang dapat menular ke manusia. Sumber penyakit tersebut berupa kotoran (ekskresi) hewan dan manusia yang telah terinfeksi Salmonella. Salmonellosis pada manusia terkenal dengan demam tifoid dan demam paratifoid yang disebabkan oleh bakteri Salmonella thypi dan Salmonella parathypi A dan B. Pada umumnya bakteri ini dapat menular melalui susu, telur, air minum dan bahan makanan yang lainnya yang telah tercemar oleh feses penderita (Safitri et al., 2017).

Hasil penelitian Fouda et al, (2016) menunjukkan bahwa pada eksoskeleton Lalat Musca domestica Linn dan Lalat
Chrysomya teridentifikasi bakteri yang didominasi oleh genus Staphylococcus sp dan Escherichia coli. Menurut Kassiri et al, (2012) Lalat Musca domestica Linn teridentifikasi mengandung bakteri Pseudomonas sp, Escherichia coli, Shigella dyptheri, Bacillus sp dan Klebsiella sp. Pada penelitian ini diketahui bahwa Lalat C.megacephala merupakan vektor pembawa bakteri Salmonella sp dan Serratia sp. Bakteri Salmonella sp dan Serratia sp mempunya anggota spesies yang dapat menginfeksi manusia. Penelitian ini menegaskan keberadaan Lalat C.Megacephaladi Pasar Mojosongo mempunyai peranan dalam Dunia Kesehatan. Lalat C.megacephala yang menyukai tempat-tempat yang berbau busuk, tempat kotor, sampah, air, daging, ayam dan feses hewan. Lalat C.megacephalamampu membawa penyakit dengan cara menularkan bakteri patogen dari tempat kotor ke tempat-tempat lain yang merupakan tempat singgah dari Lalat tersebut singgah.Bakteri-bakteri patogen yang dibawa dari tempat yang telah dihinggapi lalat kemudian ditularkan melalui makanan/minuman sehat oleh lalat yang dapat menimbulkan wabah penyakit pada gangguan saluran pencernaan manusia.

\section{KESIMPULAN}

Lalat C.megacephala yang ditangkap dari Pasar Mojosongo, Surakarta membawa bakteri Serratia sp dan Salmonella sp. Bakteri Serratia sp teridentifikasi pada eksoskeleton Lalat $C$. Megacephala yang ditangkap dari Pasar 
Mojosongo, Surakarta dengan tingkat prosentase $90 \%$ dan diikuti oleh bakteri Salmonella sp dengan prosentase 63,33\%.

\section{DAFTAR PUSTAKA}

Astawa, Ida. Bagus. Budhi., Ni. Made. Adi. Tarini. 2011. Identifikasi Jenis Bakteri Dalam Air Limbah Di Rumah Sakit Sanglah. Jurnal Medika, 6(6): 1-4. Fouda, A., Fouda, M, A., Aldally, A, G., Ismael, S, B., Awad, M, A. 2016. Isolation and Identification of Bacterial Species Associated with NonBitingFlies in Egypt. Journal of Biological Sciences. 9 (4): 37-45.

Carneiro, J.S., E. M. Pires., R. M. Nogueira., H. F. Shiomi., M. A. Soares., M. A. Oliveira., I. S. Melo. 2014. Bacteria carried by Chrysomya megacephala (Fabricius, 1794) (Diptera: Calliphoridae) in Sinop, Mato Grosso, Brazil. Scientific Electronic Archives (6): 18-22.

Hestiningsih . 2004. Perbandingan bakteri kontaminan Pada lalat Chrysomya Megacephala dan Musca Domestica di tempat pembuangan sampah akhir piyungan, bantul, Yogyakarta. Jurnal Unimus 1(2): 51-58.

Ibrahim, A. W., Ajiboye. T. O., Akande T. A. \& Anibaba, O. O. 2018.Isolation and Identification of Pathogenic Microorganisms from Houseflies. Global Journal of Science Frontier Research: C Biological Science. 18 (1): 56-64.

Kassiri, H., Akbarzadeh, K., Ghaderi, A. 2012.Isolation of Pathogenic Bacteria on the House Fly, Musca domestica L. (Diptera: Muscidae), Body Surface in Ahwaz Hospitals, Southwestern Iran. Asian Pacific Journal of Tropical Biomedicine. 15 (2): S1116-S1119.
Mahlen, Steven, D. 2011. Serratia Infections: from Military Experiments to Current Practice. Clinical Microbiology Reviews. 24 (2): 755791.

Priyatno, Tri, P., Yohana. A. Dahliani, Yadi. Suryadi, I Made. Samudra, Dwi. N. Susilowati, Iman. Rusmana, Baskoro S. Wibowo, Cahyadi. Irwan. 2011. Identifikasi Entomopatogen Bakteri Merah pada Wereng Batang Coklat (Nilaparvata lugens Stal). Jurnal AgroBiogen 7(2):85-95.

Putri, Y, P. 2018. Identifikasi Bakteri Pada Tubuh Lalat Rumah (Musca domestica Linn.) Di Tempat Pembuangan Akhir Sampah (TPA) dan Pasar. Jurnal Biota. 4 (1): 29-35.

Rengkuan, W. L., Olivia. A. Waworuntu., Standy. Soeliongan. Isolasi dan identifikasi bakteri aerob yang berpotensi menyebabkan infeksi nosokomial di Irina D RSUP Prof. Dr. R. D. Kandou Manado. Jurnal e-Biomedik. 4 (2): 1-6.

Safitri, V. Hastutiek, P., Arimbi. 2017. Identifikasi Bakteri pada Eksoskeleton Lalat di Beberapa Pasar di Surabaya Identification of Bacteria on the Fly Exoskeleton in Some Markets in Surabaya. Journal of Parasite Science. 1 (1): 1-6.

Saidah, F.Y. 2011. Penelitian Mikroba Daging Sapi Di Pasar Swalayan dan Pasar Tradisional. ,Dilavet Universitas Lampung Mangkurat 21 (2): 14-24.

Sasmita R, Hastutiek P, Sunarso A, dan Yunus M. 2013. Buku Ajar Arthopoda Veteriner. Fakultas Kedokteran Hewan. Universitas Airlangga.

Soulsby EJL. 1986. Helminth, Arthropods and Protozoa of Domesticated animals. London: Bailliere, Tindall and Cassell. Pp 355.

Sukmawati, N, L., Ginandjar, P., Hestiningsih, R. 2018. Keanekaragaman Spesies Lalat Dan Jenis Bakteri Kontaminan Yang Dibawa Lalat Di Rumah Pemotongan Unggas (Rpu) Semarang Tahun 2018. Jurnal Kesehatan Masyarakat. 7 (1): 252-259. 